\title{
Circulating Glucagon After Total Pancreatectomy in Man
}

\author{
J.J.Holst, J. Holst Pedersen², F. Baldissera and F.Stadil ${ }^{2}$ \\ Institute of Medical Physiology C, University of Copenhagen, and ${ }^{2}$ Department of Surgery D, Herlev University Hospital, Denmark
}

Summary. In five totally pancreatectomized human subjects the secretion of gut-derived glucagons was stimulated by ingestion of a meal rich in fat and carbohydrates. Glucagon-like immunoreactivity in plasma, measured with an antiserum against the 6-15 sequence, increased fivefold in response to the meal. Glucagon like immunoreactivity measured with an antiserum against the $\mathrm{C}$-terminal sequence was initially normal (12-13 pmol $/ 1$ ), increased slightly (to $20 \mathrm{pmol} / \mathrm{l}$ ), and then decreased (to approximately $6 \mathrm{pmol} / \mathrm{l}$ ). The chromatographic profile of glucagon-like immunoreactivity in plasma at maximum stimulation was studied after concentration by affinity chromatography. Both assay systems identified two peaks (at Kd-values of 0.30 and $0.60-0.65$, and 0.30 and 0.70 , respectively). The position at $\mathrm{Kd} 0.70$ corresponds to that of glucagon 1-29. The same components may be identified in plasma from normal subjects. It is concluded that the human intestine is capable of generating all of the molecular forms of glucagon which normally are present in plasma.

Key words: Affinity chromatography, enteroglucagon, glicentin, glucagon 1-37, glicentin 33-69, oxyntomodulin.
It is well known that in many animals, such as the rat, dog and cat, the pancreas is not the only source of glucagon (the 3485 molecular weight peptide hormone), which was originally discovered in the pancreas [1]. However, it has been claimed by several authors that pancreatectomy removes all sources of glucagon production in man $[1,2]$.

The validity of this claim obviously depends on the sensitivity of the method of analysis, and the methods employed have generally not been sufficiently sensitive to justify statements about the absence of glucagon. We have recently studied the chromatographic profile of immunoreactive glucagon in plasma obtained in the basal state using a new system with improved sensitivity, namely concentration by affinity chromatography and subsequent gel filtration [3]. We have now applied this technique to plasma from totally pancreatectomized subjects. Furthermore, since circulating glucagonlike immunoreactivity in these patients would be derived from the gut rather than the pancreas, we chose to stimulate the secretion of the gut glucagons by administering a fat- and carbohydrate-containing meal [1].

\section{Subjects and Methods}

Five patients (age: $35-68$ years, one female) underwent total pancreatectomy, one because of carcinoma, the others because of chronic pancreatitis. At operation the pancreas, spleen, duodenum, distal sto- mach, and upper $10-20 \mathrm{~cm}$ of jejunum were removed. One of the patients also had a cholecystectomy. The present investigation, which was approved by the local Ethics Comittee and in which the patients agreed to participate, was conducted 2-4 years after pancreatectomy. All were feeling well during treatment with pancreatic enzymes and two daily doses of insulin (total daily dose between 24 and $64 \mathrm{U}$ ). To ascertain that no part of the pancreatic uncinate process remained, the completeness of pancreatectomy was evaluated by determination of the C-peptide response to glucagon. After an overnight fast and before the morning dose of insulin, $1 \mathrm{mg}$ glucagon (Novo, Denmark) was injected IV, and plasma samples were obtained at 2-5 min interval for the subsequent $20 \mathrm{~min}$, for determination of C-peptide concentration [4].

On another day, after an overnight fast, the patients received their test meal consisting of caloreen R (Roussel, Paris), strawberries, sucrose and cream with $36 \%$ fat ( $2980 \mathrm{~kJ}$ distributed as $29.3 \mathrm{~g}$ fat, $84.9 \mathrm{~g}$ carbohydrates, and $3.5 \mathrm{~g}$ protein). Blood samples were drawn into chilled tubes containing heparin and aprotinin $(500 \mathrm{KIU} / \mathrm{ml}$ Trasylol, Bayer, Leverkusen, FRG) at the times indicated in Figure 1; plasma was separated in the cold and stored at $-20^{\circ} \mathrm{C}$. Glucagon-like immunoreactivity was measured by radioimmunoassay after ethanol extraction of plasma [5] using previously characterized antisera against the glucagon sequences 6-15 and 19-29 [6-10]. Tracer was monoiodinated ${ }^{125}$ I-labelled glucagon (a gift from U. Dahl Larsen, Novo Research Institute, Bagsværd, Denmark) [11], and standards (also a gift from Novo) were highly purified porcine glucagon. Standard and unknowns (in volumes of $300 \mu \mathrm{l}$ ) were incubated with $100 \mu \mathrm{l}$ antibody solution for $24 \mathrm{~h}$ before addition of $100 \mu \mathrm{l}$ tracer solution and further incubation for $24 \mathrm{~h}$ [12]. Plasma-coated charcoal was used for separation [13]. Intra-assay coefficient of variation was $<5 \%$ in the working range and detection limit $<1 \mathrm{pmol} / 1$. Recovery of glucagon added to plasma (to yield calculated increases of $2-50 \mathrm{pmol} / \mathrm{l}$ ) ranged from 90 and $110 \%$ of expected values after correction for the extraction losses [5]. 


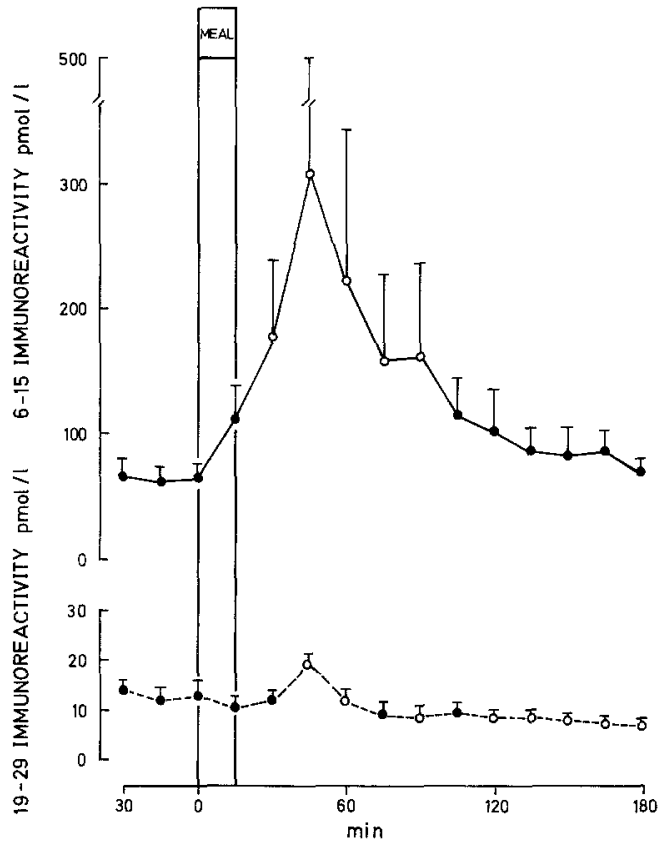

Fig. 1. Glucagon-like immunoreactivity in plasma in response to a meal in five pancreatectomized subjects. The plasma concentrations were measured with antisera against the 6-15 sequence (upper panel) or the 19-29 sequence (lower panel) of the glucagon molecule. Values shown are mean $\pm S E M$. Open circles denote values which are significantly different ( $p<0.05$, paired $t$-test) from the mean of the basal values

The samples were concentrated by affinity chromatography as previously described [3]. In short, a $20 \mathrm{ml}$ plasma sample was applied to a $1 \mathrm{ml}$ column of Sepharose-linked antiglucagon gamma globulin (reacting with the 6-15 sequence of the molecule; binding capacity $92 \mathrm{pmol} / \mathrm{ml}$ as determined with application and elution of excess glucagon). After washing with the phosphate- $\mathrm{NaCl}$-albumin solution used in the assay $[5,6]$ and a $1 \mathrm{~mol} / 1$ solution of $\mathrm{NaCl}$ adjusted to $\mathrm{pH}$ 10 with ammonia, bound material was eluted with $5 \%$ formic acid. Endogenous glucagon from the rabbit in which the antisera were raised [14] was removed by several washes of the affinity columns with $20 \%$ formic acid. In control experiments in which glucagon-free buffer was applied to the columns in lieu of plasma but otherwise conducted exactly as above, it was established that no such material remained. The eluate was freeze-dried, reconstituted in $0.125 \mathrm{~mol} / 1$ $\mathrm{NH}_{4} \mathrm{HCO}_{3}$, containing in addition $\mathrm{NaCl}(0.1 \mathrm{~mol} / 1)$, thiomersal $(0.6$ $\mathrm{mmol} / \mathrm{l}$ ), and $0.1 \%$ human serum albumin (Behringwerke, Marburg/ Lahn-FRG) and subjected to Sephadex G 50 gel filtration in the same buffer, as previously described [3]. Columns were $16 \times 1000 \mathrm{~mm}$ (K 16/100, Pharmacia, Uppsala, Sweden) and operated at $4{ }^{\circ} \mathrm{C}$; trace amounts of ${ }^{125}$ I-labelled albumin and ${ }^{22} \mathrm{NaCl}$ were added to all samples for internal calibration. Elution positions are referred to by their coefficient of distribution, $\mathrm{Kd}$, calculated as $\mathrm{Kd}=\left(\mathrm{V}_{\mathrm{e}}-\mathrm{V}_{\mathrm{o}}\right) / \mathrm{V}_{\mathrm{i}}$, where $V_{e}$ is elution volume of the substance in question, $V_{o}$ is the excluded volume, and $V_{i}$ the available inner volume, determined as the difference between the elution volumes of labelled albumin and ${ }^{22} \mathrm{Na}^{+}$. The recovery of glucagon subjected to adsorption/desorption on the affinity columns was better than $80 \%$ as judged from experiments with application of mixtures of labelled and unlabelled glucagon. The overall recovery of a small amount of glucagon $(640 \mathrm{fmol}$ ) applied to the affinity columns, eluted, and subjected to gel filtration was in two experiments $43 \%$ and $55 \%$, and the chromatographic profile was similar to that of untreated glucagon. In a similar experiment with $1 \mathrm{pmol}$ glicentin the recovery was $51 \%$ and its chromatographic profile remained intact; in particular, C-terminal immunoreactivity was not generated by the procedure. Plasma insulin was measured as described by Albano et al. [15].
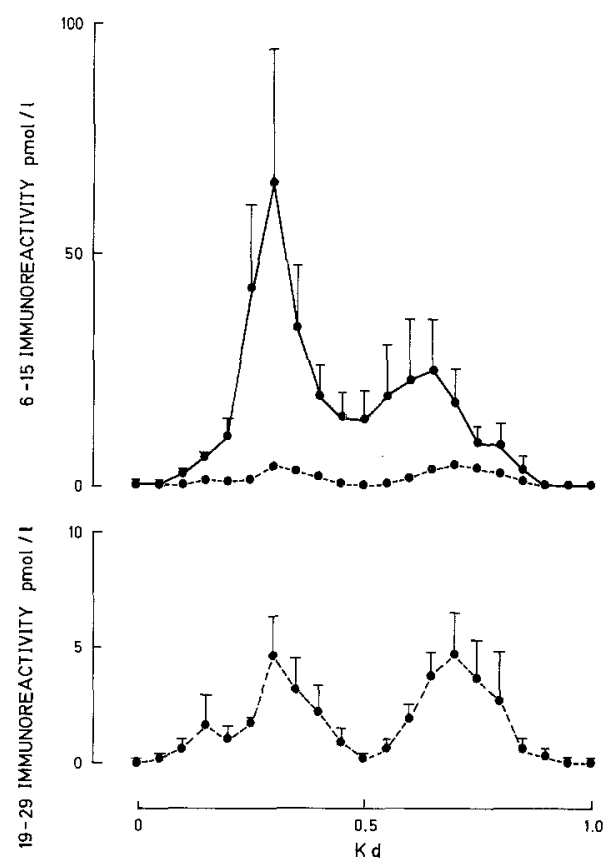

Fig. 2. Chromatographic profile of glucagon-like immunoreactivity in plasma samples from five pancreatectomized subjects. Plasma $(20 \mathrm{ml})$ was concentrated by affinity chromatography and subjected to Sephadex G-50 chromatography with subsequent radioimmunoassay of the column effluent using antisera against the 6-15 or the 19-29 sequence of the glucagon molecule. For each individual profile, $\mathrm{Kd}$ values were calculated and the effluent concentrations read off the elution curve; the figure shows mean values \pm SEM. The 19-29 immunoreactivity profile (dotted lines) is shown in a different scale in the lower panel

\section{Statistical Analysis}

The results are presented as mean \pm SEM, and significance of differences tested by paired $t$-tests. Statistical significance was taken at a level of $p<0.05$.

\section{Results}

Basal levels of C-peptide were below detection limit in all patients and there were no increases after glucagon administration. Basal glucose levels ranged between 6 and $15 \mathrm{mmol} / 1$, and the meal-induced increases ranged from $18-39 \mathrm{mmol} / 1$. After $3 \mathrm{~h}$, glucose values were again close to fasting levels. Insulin was measurable in four patients, but not in the fifth because of antibodies, and was $119 \pm 58 \mathrm{pmol} / \mathrm{l}$ in the fasting state (normal levels $70 \mathrm{pmol} / \mathrm{l}$ ), increasing gradually to a maximum of $374 \pm 86 \mathrm{pmol} / 1$ at $150 \mathrm{~min}$. The glucagon results are shown in Figure 1. The immunoreactivity determined with the 6-15 reactive antiserum increased from a mean basal level of $63.5 \pm 12.8$ to $307 \pm 193 \mathrm{pmol} / 1$ at $45 \mathrm{~min}$. Significant elevations persisted for $90 \mathrm{~min}$.

The immunoreactivity determined with the 19-29 reactive antiserum increased significantly from a mean basal level of $13.2 \pm 1.40$ to $19.0 \pm 2.0 \mathrm{pmol} / 1$ at $45 \mathrm{~min}$, and later decreased gradually, reaching $7.2 \pm 1.4 \mathrm{pmol} / 1$ at the end of the test. Samples for chromatographic 
characterization were obtained $60 \mathrm{~min}$ after the meal. The chromatographic profile is shown in Figure 2. When the column effluent was measured with the 6-15 reactive antiserum two peaks at $\mathrm{Kd} 0.30$ and $0.6-0.65$ were clearly visible. When measured with the 19-29 reactive antiserum significant peaks were observed at $\mathrm{Kd} 0.30$ and 0.70 .

\section{Discussion}

The reliability of the chromatographic analysis employed in the present investigation depends on: (1) the efficiency of concentration obtained by affinity chromatography, (2) lack of interference by endogenous ligands bound to the antibodies employed [12], (3) absence of selectivity of the affinity columns for the different molecular forms present in the applied samples, and (4) efficiency and sensitivity of the subsequent gel filtration and radioimmunoassay.

The affinity chromatography allowed us to study the chromatographic profile of glucagon-like immunoreactivity in $20 \mathrm{ml}$ of plasma $(-20 \%)$ instead of the usual 2-3 ml. When we compared the profiles of samples with higher concentrations of pancreatic and gut glucagons with or without prior affinity chromatography no differences $s_{\text {w }}$ were found [3], indicating that the columns did not exhibit selectivity for certain molecular forms when operated as described here. Washing with $20 \%$ formic acid efficiently removed endogenous ligands from the columns, and the sensitivity of the gel filtration and radioimmunoassay procedure was sufficient to allow the study of less than $60 \mathrm{fmol}$ of glucagon, corresponding to a sample concentration of approximately 3.pmol/1 [3], well below the range of concentrations in the samples studied here. On this background we believe that the profile shown here (Fig. 2) reliably reflects the true profile in plasma of pancreatectomized patients.

The absence of an insulin C-peptide response to the glucagon test in all patients attests to the completeness of pancreatectomy. The glucagon-like material found in the plasma is therefore derived from extrapancreatic tissues, probably from the gut [16]. The intestinal mucosa of man like the pig $[1,7,9,16]$ contains several peptides with glucagon-like immunoreactivity, among these one which is similar in size to the porcine glicentin [17, 18], another is similar, if not identical, to the porcine "peak II enteroglucagon' (glicentin 33-69 [10]), the two predominating components of the porcine intestinal mucosa [16]. Both of these molecules contain the entire glucagon sequence plus an 8 amino-acid C-terminal extension, which means that they are measurable in assays for the $6-15$ sequence, but not in assays for the C-terminus $[10,19]$. Because of this, and because of the similar elution positions on our columns, it is probable that the two plasma components correspond to the two predominating components of the human tissue extracts.
The human intestinal mucosa also contains small amounts of two peptides with C-terminal immunoreactivity and elution positions very similar to those of the components with C-terminal immunoreactivity observed here [17]. One of the tissue peptides has the size of glucagon and binds to hepatic glucagon receptors [17]; it may therefore be identical to glucagon. Possibly, the two components identified in plasma from pancreatectomized patients are identical to the forms found in human tissue extracts. However, the presence in plasma of these components with C-terminal immunoreactivity might also be due to hydrolysis within the circulation of the components with C-terminal extensions as suggested by Korany et al. [20]. This mechanism might also explain the initial increase in the concentration of C-terminal immunoreactivity, which coincided with the peak of the 6-15 immunoreactivity response to the test meal.

The chromatographic profile observed here is very similar to the profile found in normal subjects [3]; this means that small amounts of a peptide which is similar, if not identical, to glucagon remains in the circulation after pancreatectomy in man. In addition a component is found which may be similar to glicentin 33-69. Both components will probably possess glucagon-like bioactivity $[9,17,21]$. It is unlikely, therefore, that pancreatectomy in man causes complete glucagon deficiency. However, since the secretion of extrapancreatic glucagons seems to be regulated by other stimuli than those affecting pancreatic glucagon [16], it is possible that pancreatectomy causes a functional glucagon deficiency.

Acknowledgements. We thank M. Hagerup for expert technical assistance. Dr. B. Tronier of the Novo Research Institute performed the Cpeptide determinations, for which we are very grateful. This investigation was supported by grants from the Danish Medical Research Council and Landsforeningen for Sukkersyge.

\section{References}

1. Holst JJ (1978) Extrapancreatic glucagons. Digestion 17: 168-190

2. Tiengo A, Bessioud M, Valverde I, Tabbi-Anneni A, Delprato S, Alexandre J, Assan R (1982) Absence of islet alpha cell function in pancreatectomized patients. Diabetologia 22: 25-32

3. Holst JJ (1983) Molecular heterogeneity of glucagon in normal subjects and in patients with glucagon producing tumours. Diabetologia 24: 359-365.

4. Faber OK, Binder C (1977) C-peptide response to glucagon. A test for the residual beta-cell function in diabetes mellitus. Diabetes 26: $605-610$

5. Heding LG (1971) Radioimmunological determination of gut and pancreatic glucagon in plasma. Diabetologia 7:10-19

6. Holst JJ, Åsted B (1974) Production and evaluation of glucagon antibodies for radioimmunoassay. Acta Endocrinol (Copenh) 77 : 715-726

7. Holst JJ (1980) Evidence that glicentin contains the entire glucagon sequence. Biochem J 187: 337-343

8. Holst JJ (1977) Extraction, gel filtration and receptor binding of porcine gastrointestinal glucagon-like immunoreactivity. Diabetologia 13: 159-169 
9. Holst JJ (1977) Interactions of hepatocyte membrane receptors with pancreatic and gut glucagon. In: Foa PP, Bajaj JS, Foa NL (eds) Glucagon: its role in physiology and clinical medicine. Springer Verlag, New York, pp 287-303

10. Holst JJ (1982) Evidence that peak II GLI or enteroglucagon is identical to the C-terminal sequence (residues 33-69) of glicentin. Biochem J 207: 381-388

11. Jørgensen KH, Larsen UD (1972) Purification of 125-I-glucagon by anion exchange chromatography. Horm Metab Res 4: 223-224

12. Holst JJ, Kreutzfeldt M, Holm G, Jensen E, Poulsen JSD, Spars $\varnothing$ B, Sparsø B, Schmidt A (1978) Absence of true pancreatic glucagon but persistence of circulating pancreatic glucagon-like immunoreactivity after pancreatectomy in pigs. Diabete Metab 4: $75-79$

13. Stadil F, Rehfeld JF (1973) Determination of gastrin in serum. An evaluation of the reliability of a radioimmunoassay. Scand J Gastroenterol 8: 101-112

14. Grønholt R, Holst JJ (1983) Stripping of endogenous ligands from antisera against glucagon. J Immunol Methods 58: 83-91

15. Albano JDM, Ekins RP, Maritz G, Turner RC (1972) A sensitive precise radioimmunoassay of serum insulin relying on charcoal separation of bound and free hormone moieties. Acta Endocrinol (Kbh) 70: 487-509

16. Holst JJ (1983) Gut glucagon, enteroglucagon, gut GLI, glicentin current status. Gastroenterology 84: 1602-1613

17. Baldissera FA, Holst JJ (1983) Glucagon-related peptides in the human gastrointestinal mucosa. Diabetologia (in press)
18. Thim L, Moody AJ (1981) The primary structure of porcine glicentin (proglucagon). Regulatory Peptides 2: 139-150

19. Yanaihara N, Yanaihara C, Nishida T, Hiraiwa T, Mihara S, Sakagami M, Ozaki J, Imagawa K, Shin S (1979) Synthesis of glicentinand proglucagon-related peptides and their immunological properties. In: Rosselin G, Fromageot P, Bonfils S (eds) Hormone receptors in digestion and nutrition. Biomedical Press, Elsevier/ North Holland, pp 65-68

20. Koranyi L, Peterfy F, Szabo J, Török A, Guoth M, Tamas GY (1981) Evidence for transformation of glucagon-like immunoreactivity of the gut into pancreatic glucagon in vivo. Diabetes 30 : $792-794$

21. Bataille D, Tatemoto K, Gespach C, Jörnvall H, Rosselin G, Mutt $V$ (1982) Isolation of glucagon-37 (bioactive enteroglucagon/ oxyntomodulin) from porcine jejuno-ileum. Characterization of the peptide. FEBS Lett 146: 79-86

Received: 24 January 1983

and in revised form: 11 July 1983

Dr. J.J.Holst

Institute of Medical Physiology C

Panum Institute, University of Copenhagen

Blegdamsvej 3C

DK-2200 Copenhagen $\mathrm{N}$

Denmark 